\title{
PRINSIP-PRINSIP BERDEMOKRASI BAGI PENYANDANG DISABILITAS TUNA GRAHITA PADA PEMILIHAN UMUM 2019 DI PROVINSI RIAU
}

\author{
Hernimawati Hernimawati ${ }^{1}$, Yulianti Asyar ${ }^{2}$, Adrian Faridhi $^{3}$, Alexsander Yandra $^{4}$ \\ 1,2, ${ }^{2}$ Ilmu Administrassi Negara, Universitas Lancang Kuning, Pekanbaru, Indonesia \\ ${ }^{3}$ Ilmu Hukum, Universitas Lancang Kuning, Pekanbaru, Indonesia \\ alexsy@unilak.ac.id
}

\begin{abstract}
ABSTRAK
Penelitian ini mengkaji tentang penerapan prinsip berdemokrasi bagi penyandang disabilitas tuna grahita dalam Pemilihan Umum (Pemilu) tahun 2019 di Provinsi Riau. Berkembangnya informasi dimedia elektronik dan sosial terkait orang gila memilih menjadi perhatian serius peneliti untuk mengkaji kategorisasi kelompok disabilitas tuna grahita yang terganggunya fungsi pikir karena kecerdasan di bawah rata rata. Data menunjukkan bahwa penyandang disabilitas tuna grahita diprovinsi Riau pada Pemilu 2019 sebanyak 911 orang namun tingkat partisipasi penyandang disabilitas hanya 411 orang atau lebih kurang $48 \%$. Melalui pendekatan prinsip-prinsip demokrasi dan metode kualitatif analitis fenomenologi terlihat bahwa rendahnya partisipasi politik penyandang disabilitas tuna grahita dalam berdemokrasi disebabkan oleh inefektifnya pola penerapan prinsip berdemokrasi bagi penyandang disabilitas tuna grahita yang cendrung simetris, sehingga berdampak terhadap terbatasnya aksesibilitas penyandanng disabilitas dalam pemenuhan kebutuhan informasi kepemiluan. Oleh karena itu, penelitian ini mencoba memberikan masukkan dampak simetris maupun asimetris keterlibatan penyandang disabilitas dalam Pemilu.
\end{abstract}

\section{Kata Kunci: Demokrasi, Pemilu dan Partisipasi}

\section{PENDAHULUAN}

Pemilihan Umum (Pemilu) merupakan salah satu cara dalam sistem demokrasi untuk memilih serta salah satu bentuk pemenuhan hak asasi warga Negara dibidang politik (lutfi Syafirullah 2014). Berbicara tentang demokrasi tentunya tidak bisa lepas dari politik, karena untuk mewujudkan negara yang demokratis diperlukan partisipasi politik yang aktif dari warga masyarakat. Pemilu sebagai sarana demokratisasi telah digunakan di sebagian negara tidak terkecuali Indonesia yang notabene memiliki masyarakat yang heterogen. Indonesia menyelenggarakan pesta demokrasi dengan tujuan untuk memilih anggota Legislatif dan Eksekutif Presiden/Kepala Daerah (Eta Yuni Lestari, Nugraheni Arumsari).

Prinsip demokrasi merupakan seperangkat nilai yang menjadi dasar terwujudnya sistem politik demokratis, prinsip-prinsip demokrasi berperan penting sebagai panduan dan tolak ukur keberhasilan suatu negara atau pemerintahan dalam mewujudkan sistem politik yang demokratis. Tanpa adanya prinsip demokrasi, tak hanya orientasi politik yang menjadi kabur, makna 
NAKHODA:

JURNAL

ILMU PEMERINTAHAN
NAKHODA: JURNAL ILMU PEMERINTAHAN

Edisi Januari - Juni 2019 Volume: 18 Nomor: 1

ISSN : 1829-5827 | E-ISSN : 2656-5277

DOI : https://doi.org/10.35967/jipn

https://nakhoda.ejournal.unri.ac.id/index.php/JIPN diselenggarakannya pemerintah itu sendiri juga semakin absurd. Persoalan yang tidak kalah penting untuk meneggakkan prinsip demokrasi adalah keterlibatan rakyat atau masyarakat maupun penyandang disabilitas secara langsung (Marzuki, 2012:394-395).

Jika diperhatikan pelaksanaan Pemilu di Indonesia tahun 2019 beragam masalahnya, salah satunya di Provinsi Riau terkait keterlibatan penyandang disabilitas. Keterlibatan penyandang disabilitas menjadi problematik tersendiri ketika secara umum tidak adanya perbedaan dalam pemberian hak suara sewaktu pencoblosan berlangsung. Terdapat empat pengelompokan disabilitas, ada disabilitas fisik, disabilitas intelektual, disabilitas mental, dan disabilitas sensorik. Namun sebaliknya isu-isu yang tersebar di media elektronik dan sosial yang dapat diakses publik terkait orang gila memilih menjadi perhatian serius sebagai kategoresasi kelompok disabilitas intelektual. Penelitian ini memfokuskan pada disabilitas intelektual yang disebabkan oleh terganggunya fungsi pikir karena kecerdasan di bawah rata rata. Contohnya, Tuna Grahita, lambat belajar, dan down syndrome. Tuna Grahita adalah seseorang yang memiliki kapasitas intelektual (IQ) di bawah rata rata yang disertai ketidak mampuan dalam penyesuaian diri dengan lingkungan sehingga memiliki berbagai masalah sosial.

Dalam rentang waktu pelaksanaan Pemilihan umum gubernur riau dan pemilihan umum 2019 penyandang disabilitas tuna grahita yang semakin meningkat setiap tahunnya, Data tingkat pemilih tetap penyandang disabilitas Tuna Grahita tahun 2018-2019 :
Tabel 1. Jumlah Disabilitas Tuna Grahita di Provinsi Riau 2018-2019

\begin{tabular}{|c|l|c|}
\hline No & Tahun & $\begin{array}{c}\text { Jumlah disabilitas } \\
\text { tuna grahita }\end{array}$ \\
\hline 1. & 2018 pilgubri & 660 pemilih \\
\hline 2. & 2019 pemilu & 911 pemilih \\
\hline & Selisih & 251 pemilih \\
\hline
\end{tabular}

Sumber : KPUD Provinsi Riau

Berdasarkan tabel diatas juga bisa dilihat untuk pemilih disabilitas Tuna Grahita di Provinsi Riau datanya meningkat rentang tahun 2018-2019 yaitu pada pelaksanaan Pemilihan Umum daerah Provinsi Riau (pilgubri) 2918 dan Pemilihan Umun (pemilu) 2019. Hal tersebut bertolak belakang dengan partisipasi penyandang disabilitas tuna grahita dalam Pemilu 2019 yang justru menurun, sebagaimana terlihat dari tabel Berikut Data Pemilih Politik Penyandang Disabilitas Tuna Grahita yang memilih dalam Pemilu 2019 di Provinsi Riau.

Tabel 2. Data Pemilih Politik Penyandang Disabilitas Tuna Grahita yang memilih dalam Pemilu 2019 di Provinsi Riau

\begin{tabular}{|c|c|c|}
\hline Tahun & $\begin{array}{c}\text { Tuna Grahita } \\
\text { yang memilih }\end{array}$ & $\begin{array}{c}\text { Yang tidak } \\
\text { memilih }\end{array}$ \\
\hline 2019 & 411 & 501 \\
\hline \multicolumn{3}{|c|}{ Sumber : KPUD Provinsi Riau }
\end{tabular}

Tabel diatas data pemilih tuna grahita yang berpartisipasi tidak sebanding yang ikut berpatisipasi. Yang berpartisipasi hanya 411 sedangkan yang tidak memilih mencapai 501, jadi bisa dilihat bahwa partisipasi penyandang disabilitas tuna grahita dalam memberikan hak suaranya sangat kurang. Partisipasi politik pastinya 
NAKHODA:

JURNAL

ILMU PEMERINTAHAN
NAKHODA: JURNAL ILMU PEMERINTAHAN

Edisi Januari - Juni 2019 Volume: 18 Nomor: 1

ISSN : 1829-5827 | E-ISSN : 2656-5277

DOI : https://doi.org/10.35967/jipn

https://nakhoda.ejournal.unri.ac.id/index.php/JIPN merupakan indikator keberhasilan suatu demokrasi, yang mana keterlibatan masyarakat secara sadar merupakan nilai meningkatnya kualitas demokrasi. Peningkatan kualitas demokrasi tentu tidak dinilai dari prosedural saja tetapi dinilai secara substansial. Oleh karena itu partisipasi kelompok disabilitas merupakan bahagian dari suksesnya pelaksanaan demokrasi. Dinamika pelaksanaan demokrasi tentunya dapat ditelusuri dengan mengkaji secara mendalam penerapan prinsip-prinsip demokrasi dalam pelaksanaan pemilu.

Realitas iniliah yang menjadi persoalan menarik dalam penelitian ini dimana pemilih disabilitas tuna grahita meningkat, namum apakah linear dengan partisipasinya dalam memberikan hak suara. Menurut (Putu Ratih Kumala Dewi:2015) Menurunnya angka partisipasi ini kontraproduktif dengan jaminan pelaksanaan hak politik tanpa deskriminasi terutama pada kalangan penyandang disabilitas. Partisipasi politik penyandang disabilitas tuna grahita ini menjadi sangat penting dalam rangka menyiapkan sebuah basis rujukan dalam pemberdayaan dan penguatan kapasitas kelompok marjinal difabel. Pentingnya agar penguatan partisipasi politik tidak lagi terjebak pada hiruk piruk pencoblosan saja, namun secara substansial juga memberikan dorongan kepada komunitas ini untuk melakukan gerakan perubahan (Rachmad Gustomy:2017).

Menurut Christine Susanna Tjhin (2014), memberikan beberapa hal yang merupakan prinsip-prinsip demokrasi yang penting, antara lain Partisipasi (Participation), Kesetaraan (Equality), Transparansi (Transparency), Pertanggung jawaban atau Akuntabilitas (Accountability), Kecepatan Merespon (Responsiveness). Zamroni (2011: 15) mengutarakan sebuah pendapat yang menyatakan bahwa ada dua prinsip utama di dalam demokrasi. Sebagaimana berikut yakni kompetisi yang bebas jujur dan adil diantara para kandidat, dan keikutsertaan bagi seseorang yang telah dewasa serrta telah mempunyai hak politik. Sedangkan Maswadi Rauf (1997:14) bahwa di dalam demokrasi terdapat dua prinsip utama atau pokok: kebebasan atau persamaan (freedom atau equality), kedaulatan rakyat (people's sovereignty). Tentunya penerapan prinsip-prinsip demokrasi bagi penyandang disabilitas tuna grahita perlu meninjau kepatutan dalam memberikan aspirasi secara rasional sehingga tidak menimbulkan polemik.

\section{KERANGKA TEORI}

Menurut Christine Susanna Tjhin (2014), memberikan beberapa hal yang merupakan prinsip-prinsip demokrasi yang penting, antara lain :

\section{Partisipasi (Participation)}

Demokrasi pada esensinya melibatkan aspirasi masyarakat dalam menjalankan perannya secara aktif dan menentukan dalam proses politik. Partisipasi adalah elemen penting dalam pemberdayaan. Partisipasi tidak hanya berupa 'mencoblos' dalam pemilihan umum/pemilihan kepala daerah yang dilaksanakan secara rutin. Partisipasi menjamin keterlibatan dalam prosesnya. Tetapi, semua ini harus didasarkan pada asumsi bahwa hak-hak untuk berpartisipasi itu memang sudah eksis dan masyarakat/warganegara memiliki 
NAKHODA:

JURNAL

ILMU PEMERINTAHAN
NAKHODA: JURNAL ILMU PEMERINTAHAN

Edisi Januari - Juni 2019 Volume: 18 Nomor: 1

ISSN : 1829-5827 | E-ISSN : 2656-5277

DOI : https://doi.org/10.35967/jipn

https://nakhoda.ejournal.unri.ac.id/index.php/JIPN kapasitas dan sumber daya yang layak untuk berpartisipasi, dan pemerintah telah menyediakan jalur-jalur dan institusiinstitusi politik (di mana melalui semua itu masyarakat bisa berpartisipasi).

\section{Kesetaraan (Equality)}

Setiap individu dipandang setara secara politik. Dengan kata lain setiap individu diperlakukan sebagai warganegara terlepas dari perbedaan latar belakang ras, etnis, kelas, gender, agama, bahasa, maupun identitas lain termasuk disabilitas. Demokrasi mendorong pluralitas dan keberagaman, juga mengelola keberagaman tersebut tanpa kekerasan. Demokrasi tidak bisa eksis jika perolehan hak-hak dasar dibatasi secara diskriminatif. Demokrasi juga harus mengawal sektor-sektor masyarakat yang termarjinalisasi melalui pelaksanaan kebijakan afirmatif untuk bisa mencapai kesamaan status dan pemberdayaan. Kebijakan afirmatif ini haruslah bebas dari prasangka/stereotip.

\section{Transparansi (Transparency)}

Karena demokrasi berarti bahwa institusi-institusi publik mendapatkan otoritas mereka dari masyarakat, maka harus ada perangkat yg memungkinkan masyarakat untuk mengawasi dan mengawal institusi-institusi publik tersebut. Masyarakat atau kelompok yang ditunjuk oleh masyarakat harus diberikan kesempatan untuk mempertanyakan kinerja dan kerja institusi-institusi publik tersebut. Terlebih lagi, segala informasi mengenai proses kerja dan kinerja mereka harus bisa dijangkau oleh publik dan media massa.

\section{Pertanggung jawaban atau Akuntabilitas (Accountability)}

Akuntabilitas sangatlah penting dlm demokrasi karena hal inilah yang akan menjamin agar wakil-wakil rakyat yang memegang mandat populer tidak menyimpang dari jalur mandat dan fungsi mereka. Akuntabilitas mengharuskan wakil-wakil rakyat tersebut bertanggung jawab atas sikap dan perbuatan mereka, dan jika sampai terjadi penyimpangan, penjatuhan sanksi kepada pihak-pihak yang bertanggung jawab harus menjadi bagian dari akuntabilitas ini.

\section{Kecepatan Merespon (Responsiveness)}

Dalam demokrasi, institusi-intitusi publik atau negara harus dapat diakses oleh kelompok-kelompok masyarakat yg berbeda. Institusi-institusi ini harus siap utk merespon tuntutan-tuntutan warga negara dalam setiap proses pembuatan kebijakan secara cepat dan bijak. Kemampuan institusi-institusi tersebut dalam mengantarkan pelayanan (service delivery) menunjukkan kualitas dari institusi-institusi tersebut dan pada akhirnya, kualitas dari demokrasi itu sendiri.

Konsep teoritis diatas relevan dengan mengkaji bagaimana pelaksanaan hak politik bagi penyandang disabilitas tuna grahita, apakah secara procedural asimetris atau sebaliknya perlu adanya prosedur asimetris sehingga adanya alternative lain dalam memberikan kesempatan bagi penyandang disabilitas tuna grahita untuk tetap berpartisipasi dalm pemilu

\section{METODE PENELITIAN}

Penelitian ini menggunakan metode kualitatif dengan teknik penarikan 
NAKHODA:

JURNAL

ILMU PEMERINTAHAN
NAKHODA: JURNAL ILMU PEMERINTAHAN

Edisi Januari - Juni 2019 Volume: 18 Nomor: 1

ISSN : 1829-5827 | E-ISSN : 2656-5277

DOI : https://doi.org/10.35967/jipn

https://nakhoda.ejournal.unri.ac.id/index.php/JIPN informan mengutamakan kualitas data yang diperoleh melalui penyampaian informan terkait dengan masalah penelitian. Untuk mendapatkan data yang tepat dan relevan, peneliti menggunakan beberapa teknik pengumpulan data, yakni: wawancara mendalam (indepth interview) dan dokumentasi dan mengumpulkan datadata fenomena yang bisa di verifikasi dan membuat kesimpulan sehingga mudah dipahami oleh diri sendiri maupun orang lain (Yandra 2015:9). Seluruh data yang didapat akan dianalisis dengan menggunakan metode kualitatif melalui interpretasi fenomenologi. Proses ini mengklafikasikan data ke dalam dua bagian, yaitu data etik (dari teori) dan data emik (dari temuan di lapangan). Selanjutnya proses reduksi hasil analisa data dapat menjadi terukur dan mampu dipertanggung jawabkan secara ilmiah bahkan menjadi temuan baru dalam mengembangkan teori partisipasi politik khususnya bagi penyandang disabilitas tuna grahita. Selanjutnya partisipasi politik secara simetris dengan partisipasi politik secara asimetris menjadi dua bahagian yang pembeda serta model seperti apa yang tepat untuk panyandang disabilitas tuna grahita.

\section{HASIL DAN PEMBAHASAN}

\section{A. Pergerakan data penyandang disabillitas Tuna Grahita}

Partisipasi politik merupakan kondisi yang menyangkut hak setiap warga Negara dibidang politik, tak terkecuali kalangan penyandang disabilitas. Hanya saja keikutsertaan kalangan penyandang disabilitas Tuna Grahita masih rendah. Padahal keberadaan kalangan penyandan disabilatas tidak bisa diabaikan, partisipasi politik merupakan kondisi yang menyangkut hak asasi warga Negara dibidang politik, tak terkecuali kalangan penyandang disabilitas dalam akses partisipasi politik masih sering kali dianggap tidak penting.

Tabel 3. Partisipasi Politik Pemilih Penyandang Disabilitas Tuna Grahita

\begin{tabular}{|c|c|c|c|c|c|}
\hline \multicolumn{6}{|c|}{ Provinsi Riau } \\
\hline \multirow{3}{*}{$\begin{array}{l}\text { Pemilih } \\
\text { Tuna } \\
\text { Grahita }\end{array}$} & DP & DP & DP & DPTH & DPT \\
\hline & 4 & $\mathrm{~S}$ & $\mathrm{~T}$ & $\mathrm{P} 1$ & HP2 \\
\hline & $\begin{array}{l}66 \\
0\end{array}$ & $\begin{array}{l}88 \\
8\end{array}$ & 888 & 911 & 911 \\
\hline
\end{tabular}

Sumber : KPUD Provinsi Riau

Tabel di atas juga menggambarkan pegerakan data pemilih penyandang disabilitas Tuna Grahita mengalami peningkatan yang bisa dilihat dari DP4, DPS, DPT, DPTHP1 dan DPTHP2. Pegerakan pemilih Tuna Grahita ini sebanding dengan pergerakan peningkatan pemilih di Provinsi Riau. Komitmen KPUD dalam upaya mendorong pemilih disabilitas khusunya tuna grahita untuk ikut berpartisipasi dalam pemilu 2019 seiring dengan isu keterlibatan orang gila mencoblos diberbagai informasi media. Kernyataannya bahwa orang gila itu tidak ada memilih, namun yang dimaksut itu adalah pemilih yang mempunyai keterbelakangan mental atau lebih dikenal dengan tuna grahita. Selanjutnya berdasarkan tinjauan peneliti terkait pergerakan data pemilih tuna grahita, peningkatan jumlah pemilih tersebut berada pada daerah Kota Pekanbaru.

Tuna grahita yang mempunyai hak memilih adalah yang tidak atau sedang dalam masa perawatan, artinya bahwa para pemilih disabilitas tuna grahita yang 
NAKHODA:

JURNAL

ILMU PEMERINTAHAN
NAKHODA: JURNAL ILMU PEMERINTAHAN

Edisi Januari - Juni 2019 Volume: 18 Nomor: 1

ISSN : 1829-5827 | E-ISSN : 2656-5277

DOI : https://doi.org/10.35967/jipn

https://nakhoda.ejournal.unri.ac.id/index.php/JIPN mendapatkan hak pilih yang secara prosedur sudah dinyatakan sehat dengan adanya surat keterangan kesehatan dari dokter atau pihak rumah sakit. Dengan hal tersebut peningkatan jumlah pemilih disabilitas tuna grahita menjadi meningkat 251 pemilih, terlihat dari data pemilih pada Pilgubri 2018 dengan Pemilu 2019 (KPUD Riau: 2019).

\section{B. Penerapan Prinsip prinsip demokrasi bagi penyandang disabilitas Tuna Grahita dalam pemilihan umum 2019 di Provinsi Riau}

Penyandang Disabilitas adalah orang yang memiliki keterbatasan fisik, mental intelektual atau sensorik dalam jangka waktu lama. Dalam berinteraksi dengan lingkungan dan masyarakatnya kelompok disabilitas dapat menemui hambatan yang menyulitkan untuk berpartisipasi penuh dan efektif. Bukan hanya fisik atau jiwa, namun merupakan fenomena yang terdiri dari fungsi tubuh, keterbatasan aktivitas, hambatan partisipasi dan faktor lingkungan menjadi kendala yang tidak dapat dipungkiri (Sandra Febriyani Nur R:2015)

Penerapan prinsip-prinsip demokrasi bagi penyandang disabilitas tuna grahita dalam pemilu 2019, dalam kontek demokrasi bahwa pemilih adalah aspek yang paling penting dalam suksesnya suatu penyelenggara pemilu. Oleh karena itu, perlu mengkaji keterlibatan penyandang disabilitas tuna grahita untuk berperan aktif dalam pemilu, serta seperti apakah model yang tepat untuk menerapkan prinsip-prinsip demokrasi bagi pemilih tuna grahita. Adapun dasar pembahasan adalah teori Christine Susanna Tjhin prinsip-prinsip demokrasi.

\section{Partisipasi Kelompok Disabilitas Tuna Grahita \\ Demokrasi pada esensinya} melibatkan aspirasi masyarakat dalam menjalankan perannya secara aktif dan sangat menentukan dalam proses politik bahkan dalam prosedur politik perlu intesitas yang tinggi masayarakat. Partisipasi adalah elemen penting dalam pemberdayaan pemilih. Seperti Upaya peningkatan partisipasi terhadap penyandang disabilitas tuna grahita dan kriteria tuna grahita yang bisa memilih, menjadi bahagian penting dalam meningkat kualitas demokrasi yang serta merta tidak bisa disamakan khususnya dalam konteks prosedur. Pemilih disabilitas tuna grahita kemampuan rasionalitasnya masih terbatas sehingga untuk menelaah lebih jauh butuh pendamping, implikasinya hak suara dalam pemilu menjadi tidak bersifat rahasia karen diketahui oleh si pemilih lain yang melakukan pendampingan.

Peningkatan partisipasi dan kriteria sangatlah penting untuk ditetapkan agar tidak timbul pandangan masyarakat lain terhadap penyandang disabilitas tuna grahita yang ikut berperan aktif dalam berpartisipasi dalam memberikan hak suaranya.

Berdasarkan data dari KPUD Riau partisipasi politik penyandang tuna grahita dalam pemilu belum sampai pada angka partisipasi politik masyarakat riau yaitu $78 \%$. Artinya partisipasi politiknya dibawah partisipasi politik masyarakat riau yaitu $48 \%$. Perlu mekanisme yang tepat bahkan tidak harus disamakan dengan partisipasi politik masyarakat umumnya, maka dari itu model partisipasi politik asimetris sangat 
relevan bagi pemilih yang memiliki keterbalekangan mental, fisik, sensorik dll.

\section{Kesetaraan:}

Setiap individu dipandang setara secara politik begitu juga untuk kelompok disabilitas. Dengan kata lain setiap individu diperlakukan sebagai warga negara terlepas dari perbedaan latar belakang ras, etnis, kelas, gender, agama, bahasa, maupun identitas lain termasuk keterbatasan fisik (disabel). Seperti Fasilitas bagi pemilih penyandang disabilitas tuna grahita tidak harus disamakan dengan pemilih lainnya, karena setara bukan berarti harus sama tetapi setara harus menyesuaikan dengan kebutuhan untuk mencapai tujuan. Namun realitanya dalam penyelenggaraan Pemilu 2019 termasuk di Riau semua pemilih disamakan model pemilihannya, inilah yang perlu dikaji secara komprehensif untuk mencarikan alternative model asimetris bagi penyandang disabilitas tuna grahita, atau bahkan para penyandang disabilitas tuna grahita jika disamakan dengan pemilih lainnya lebih baik untuk tidak terlibat agar pilihannya tidak anomaly.

Oleh karena itu, pelayanan bagi kelompok tuna grahita lebih diutamakan kepada model alternative pendekatan sensorik agar mempermudah penyandang disabilitas Tuna Grahita tersebut, proses inilah yang selama ini tidak terlihat dalam meningkatkan kualitas demokrasi bagi penyandang disabilitas, sehingga kelompok tersebut masih procedural dalam memilih, atau hanya merepresentasikan kalau mereka ikut memilih.

\section{Transparansi}

Karena demokrasi berarti bahwa institusi-institusi publik mendapatkan otoritas mereka dari masyarakat, maka harus ada perangkat yang memungkinkan masyarakat untuk mengawasi dan mengawal institusiinstitusi publik tersebut. Seperti keterbukaan akses publik karena kinerja dalam menjalankan demokrasi seperti pemilihan umum secara informative publik bisa mengevaluassinya, terkhusus bagi penyandang disabilitas. Bagi penyandang disabilitas apa bisa dijangkau informasinya tentu sangat terbatas. Oleh karena itu, peran civil society dan media masa sangat dimungkinkan sebagai fungsi control demokrasi dan mediator terhadap kelompok disabilitas tentang kepemiluan. Bicara demokrasi berarti bahwa institusi-institusi publik yang mendapatkan otoritas dari masyarakat, harus memungkinkan masyarakat untuk mengawasi dan mengawali institusiinstitusi publik tersebut. Sehingga kelompok disabilitas tuna grahita link and match dengan penyelengara.

\section{Pertanggung \\ (Accountability)}

Akuntabilitas sangatlah penting dalam demokrasi karena hal inilah yang akan menjamin agar publik percaya dengan wakil-wakil rakyat yang memegang mandat agar tidak menyimpang dari jalur mandat dan fungsi mereka. Seperti penyandang disabilitas Tuna Grahita bisakah bertanggung jawab atas suara yang diberikannya atau sebaliknya setelah memberikan suara apa mampu 
NAKHODA:

JURNAL

ILMU PEMERINTAHAN
NAKHODA: JURNAL ILMU PEMERINTAHAN

Edisi Januari - Juni 2019 Volume: 18 Nomor: 1

ISSN : 1829-5827 | E-ISSN : 2656-5277

DOI : https://doi.org/10.35967/jipn

https://nakhoda.ejournal.unri.ac.id/index.php/JIPN bertanggung jawab lima tahunan dalam mengawal pilihannya atau orang yang dipilihnya. Penyandang disabilitas tuna grahita kurang mampu bertanggung jawab terhadap hak suaranya yang diberikannya secara stimultan, karena dalam melakukan pemilihan mereka didampingi oleh keluarganya dan diarahkan oleh keluarganya atau penyelenggara pemilu.

Inilah yang menjadi bias makna jika keterlibatan penyandang disabilitas tuna grahita untuk mampu secara substansi dalam memberikan hak pilihnya. Tetapi penyandang disabilitas diberikan hak pilih dengan cara dan metode yang berbeda, mungkin tidak harus memilih langsung tetapi keterlibatan yang intensif secara tidak langsung (indirect) dalam politik dimungkinkan untuk dilakukan seperti partisipasi dalam kebijakan, pembangunan, pemberdayaan dll.

\section{Kecepatan \\ (Responsiveness)}

Dalam demokrasi, institusi-intitusi publik atau negara harus dapat diakses oleh kelompok-kelompok masyarakat yg berbeda. Institusi-institusi ini harus siap utk merespon tuntutan-tuntutan warga negara dalam setiap proses pembuatan kebijakan secara cepat dan bijak. Seperti Isu-isu penyandang disabilitas tuna grahita yang ikut memilih, Penyandang disabilitas ini bukan orang gila sebagimana yang di informasikan oleh berbagai media yang menimbulkan multitafsir, tetapi melainkan tuna grahita itu mempunyai hak pilih namun dalam memilih dia memiliki kesulitan atau keterbatsan secara sensorik ataupun akal.
Jika selama ini sosialisasi penyelenggara pemilu khususnya KPUD berupaya meningkatkan partisipasi pemilih dengan pendidikan politik maka preferensi pilihan politik diarahkan untuk memilih secara rasional, sehingga faktor ekonomi, sosiologi, psikologi bahkan agama menjadi faktor yang tidak terlalu menentukan.

Sebaliknya tuna grahita mengalami permasalahan dalam hal mengingat, tapi apabila didampingi dalam pemberian hak suara dia bisa terbantu dalam melakukan pemberian hak suaranya. Namun realitas itu tidak ada jaminan rasionalitas itu menjadi preferensi memilih bagi tuna grahita, oleh karena itu penyelenggara pemilu perlu merespon ini dengan cara pandang yang asimetris agar ada alternative lain untuk melibtakan tuna grahita dalam pemilu.

\section{Dampak keterlibatan Penyandang Disabilitas dalam Politik}

1. Secara Prosedur cendrung simetris

Fenomena keterlibatan ataupun keikutsertaan penyandang disabilitas mental dalam aktivitas kewarganegaraan memang selalu menarik perhatian khalayak apalagi dalam politik. Bagaimanapun, siapa saja yang berpenyakit kejiwaan layak memperoleh perlakuan khusus. Ketentuan ini resmi dikukuhkan oleh pemerintah melalui regulasi. Norma-norma hukum mengatur mereka secara berbeda dibanding orang normal, mengingat, dalam kehidupan bermasyarakat, berbangsa, dan bernegara, pembedaan keduanya merupakan suatu keniscayaan. Disamping itu, Undang- 
NAKHODA:

JURNAL

ILMU PEMERINTAHAN
NAKHODA: JURNAL ILMU PEMERINTAHAN

Edisi Januari - Juni 2019 Volume: 18 Nomor: 1

ISSN : 1829-5827 | E-ISSN : 2656-5277

DOI : https://doi.org/10.35967/jipn

https://nakhoda.ejournal.unri.ac.id/index.php/JIPN
Undang Nomor 8 Tahun 2016 tentang Penyandang Disabilitas juga telah mengatur tentang hak-hak politik penyandang disabilitas, antara lain yaitu memilih dan dipilih dalam jabatan publik. Prinsipnya, semua penyandang disabilitas harus diberi akses yang setara untuk berpartisipasi dalam kehidupan politik dan publik tidak boleh dibedakan.

\section{Secara substansi inefektif}

Problematika keterlibatan penyandang disabilitas tuna grahita dalam politik secara substansi sangat terbatas sebagaimana keterbatasnnya dalam fisik, akal dan sensorik. Penerapan prinsip demokrasi sebagaimana yang sudah dibahas sebelumnya penerapannya masih belum efektif (inefektif) terlihat dari model penerapan yang simetris sehingga keikutsertaanya cendrung parsial.

Secara substansi keterlibatan penyandang disabilitas selama ini hanya sebatas ikut memilih, namun untuk mengawal pilihannya dalam lima tahun kedepan sangat tidak efektif. Dampak dari hal tersebut, pemilih disabilitas tuna grahita dipandang tidak terlalu berpengaruh dalam dinamika politik bahkan cendrung diabaikan, tetapi sewaktu momentum pemilu pemilih disabilitas tuna grahita menjadi isu yang trending. Perlu dipahami bahwa hak politik bagi penyandang disabilitas tuna grahita masih dominan pada unsur politis saja.

\section{KESIMPULAN}

Berdasarkan hasil penelitian diatas dapat disimpulkan bahwa partisipasi politik penyandang disabilitas tuna Grahita masih sebatas procedural atau keterlibatan dalam politik masih periodic serta cendrung simetris, Dengan pendekatan penerapan prinsip-prinsip demokrasi dan metode kualitatif analitis fenomenologi terlihat bahwa rendahnya partisipasi politik penyandang disabilitas tuna grahita dalam berdemokrasi disebabkan oleh infektifitasnya pola penerapan prinsip berdemokrasi bagi penyandang disabilitas tuna grahita, sehingga berdampak terhadap terbatasnya aksesibilitas penyandanng disabilitas dalam pemenuhan kebutuhan informasi kepemiluan. Perlu model asimetris dalam melibatkan pemilih disabilitas tuna grahita dalam politik dengan mencari alternative model yang tepat.

\section{DAFTAR PUSTAKA}

Budiardjo, Miriam, 2004. Dasar-Dasar Ilmu Politik. Jakarta. PT Gramedia Pustaka Utama.

Dewi, P. R. K. (2015). Aksesbilitas Partisipasi Politik Penyandang Disabilitas Dalam Pemilu Di Kota Denpasar.

Dr. Agus Pramusinto dan Dr.Wahyudi Kumorotomo, 2009. Dr.Governance Reform di Indonesia, Yogyakarta

Gatara, Sahid. 2008. Ilmu Politik; Memahami dan Menerapkan. Bandung: Pustaka Setia.

Gustomy, R. (2017). Partisipasi Politik Difabel Di 2 Kota. Indonesian Journal of Disability Studies (IJDS), 4(1), 5162

Lestari, E. Y., \& Arumsari, N. (2018). Partisipasi Politik Pemilih Pemula Pada Pemilihan Walikota Semarang Di Kota Semarang. Integralistik, 29(1), 10

Parwito. 2009. Komunikasi Politik: Media Massa dan Kampanye Pemilihan. Yogyakarta: Pustaka Pelajar 


\section{NAKHODA:}

JURNAL

ILMU PEMERINTAHAN
NAKHODA: JURNAL ILMU PEMERINTAHAN

Edisi Januari - Juni 2019 Volume: 18 Nomor: 1

ISSN : 1829-5827 | E-ISSN : 2656-5277

DOI : https://doi.org/10.35967/jipn

https://nakhoda.ejournal.unri.ac.id/index.php/JIPN
Pawestri, A. (2017). Hak Penyandang Disabilitas dalam Perspektif HAM Internasional dan HAM Nasional. Era Hukum-Jurnal Ilmiah Ilmu Hukum, 15(1).

Rahman, Arifin. 2002. Sistem Politik Indonesia. Surabaya: SIC.

Suharyanto, A. (2014). Partisipasi Politik Masyarakat Tionghoa dalam Pemilihan Kepala Daerah. JPPUMA Jurnal Ilmu Pemerintahan dan Sosial Politik Universitas Medan Area, 2(2), 151160.
Suparman Marzuki.2012. Politik Hukum Hak Asasi Manusia . Jakarta

Surbakti, Ramlan. 2010. Memahami Ilmu Politik. Jakarta: PT Grasindo.

Syafirullah, L. (2014). Penerapan Analityc Hierarchy Process (Ahp) Dalam Pemilu Pilpres RI 2014. Bianglala Informatika, 2(2).

Yandra, A. (2017). Fisibilitas Pilkada Serentak Tahap II Kota Pekanbaru Pasca Permendagri No 18 Tahun 2015. Jurnal Niara, 9(2), 62-74 